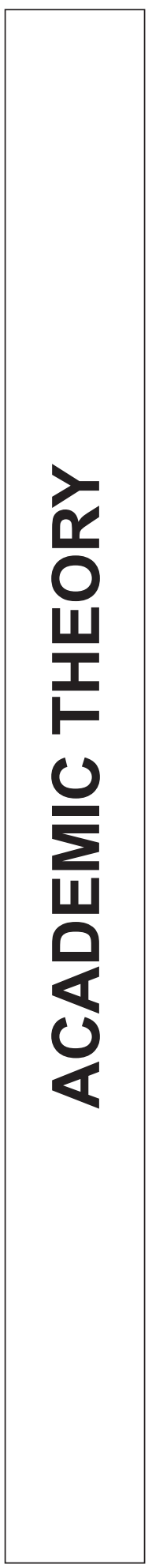





\section{DEVELOPMENT OF SOCIAL SCIENCES IN DISSERTATIONS OF IMMANUEL WALLERSTEIN - IMPLICATIONS FOR THE THEORY OF INTERNATIONAL RELATIONS}

The main issue discussed in the text is the analysis of the concept of development of social sciences by Immanuel Wallerstein. In general terms we can say that the development of social sciences was based on a process of emancipation of individual subjects of research and validation of scientific methods. Therefore, primarily, we deal with crystallisation of philosophy, followed by social sciences and, negatively evaluated by I. Wallerstein, applied social sciences. The negative assessment is primarily due to a kind of symbiosis which was formed between applied social sciences and capitalist economy. ${ }^{1}$ Therefore, in the following discussion there is that kind of symbiosis presented together with the critical reasoning of I. Wallerstein. The development of Newtonian - Cartesian research formula should be regarded as a turning point in the development of science, which facilitated adopting a specific concept of rationalisation and efficiency. A new methodological paradigm described what is purely scientific and what is not - its indicator was a specified scientific procedure. In this situation, the humanities had to adopt a defensive position; one consequence of their withdrawal was a drift towards the "good" and "beauty" as research subjects. Split in the conduct of research led to institutionalisation of the so-called two cultures of science. ${ }^{2}$

Social sciences had a problem with taking a definite stand in the clash of the two cultures; however, the need to advocate for a particular perspective contributed to the emergence of applied social sciences. The dynamics of changes in science began to manifest itself among others in specialisation, multiple narratives and competing in research, which changed into institutional rivalry. Social sciences in order to catch up with practical effects of research of the so-called "true science" had to be "servile" to authority. The functioning socio-political order is based on simple logic of efficiency and practical rationality, which forces objectification of social sciences - e.g. by reducing its reflectivity.

A consequence of the continuous development of social sciences is separation of the subsequent fields, disciplines and subdisciplines which, while attempting to bring their "scientific existence" into effect, broaden and develop their methodological and theo-

1 I. Wallerstein, Analiza Systemów - Światów. Wprowadzenie, Dialog, Warszawa 2007, pp. 13-64.

2 C. P. Snow, The Two Cultures, Cambridge University Press, London 2001. See: R. Kimball, "The Two Cultures" Today, in: The New Criterion, http://www.newcriterion.com/articles.cfm/ -The-Two-Cultures--today-4882 (30.10.2011). 
retical tools. Political sciences have taken the direction followed by international relations, or national security sciences (securitology). The question which could be asked in connection with the "microscopisation" of disciplines is the following: "Do we strive after an in-depth exploration the selected subject of research, or perhaps we only take over the research niche however not to increase the efficiency of science but for scientific flashiness, which can boil down to a slick use of metaphors?"

\section{TOWARDS EMANCIPATION OF SCIENTIFIC DISCIPLINES}

According to I. Wallerstein eighteenth/nineteenth century was a period of emancipation of social sciences, moreover, it was a time of giving a scientific nature to research on community. Social science, proclaimed themselves "sciences", while making the demarcation of philosophy. This resulted from the identification of social sciences with empiricism and philosophy with metaphysics. Social scientists became advocates for the dogma of formal rationality. ${ }^{3}$ This process is evaluated negatively by I. Wallerstein, who claims that science cannot have an uncommitted character, which results, among others, from the social context in which scientists operate.

It should be noted that I. Wallerstein does not take into account the context of the emancipation of sciences and the return to empiricism. Material rationality in sciences prior to the empirical stage should be associated with a significant influence of the Christian religion in Europe. The period before secularisation is an example of how the material rationality may adversely affect the development of science. ${ }^{4}$ It is questionable whether formal rationality itself is a doom for the social sciences. It should be emphasized that it is often the case that too broad reliance just on material rationality undermines the development of new research methods and thus blocks the development of sciences. An example here might be G. Bruno, ${ }^{5}$ who was burned at an inquisition stack in 1600. Officially, G. Bruno was condemned by the Inquisition for challenging the

3 I. Wallerstein refers in his analysis to Weber's formal and material rationality, and the purpose-rational and value-rational activities. In the first case we are dealing with economic activities, while in the latter case with the actions of a social nature. Formal rationality is based on an assessment of objectives and measures. The starting point for evaluating and selecting goals or measures are universal standards and rules. Formal rationality should be associated with over-individual forms, i.e. the administrative bureaucracy, capitalism and law. It should be noted that M. Weber and I. Wallerstein, combined capitalism with rationalisation. This is reflected in the organisation and functioning of bureaucratic, economic, scientific and legal institutions. While the material rationality is inferred from the set of values which are taken into account when choosing appropriate measures to meet specific targets. We are dealing here with a broad context (system of norms and rules of conduct), which shall be considered in human activities, and which is the reference point for every choice of objectives and measures. The key issue here is the consistency of the value system, which provides for the effective operation of processes of rationalisation. See: R. Brubaker, The Limits of Rationality: An Essay on the Social and Moral Thought of Max Weber, George Allen and Unwin, London 1984, p. 9; M. Weber, Gospodarka i społeczeństwo, PWN, Warszawa 2002 and I. Wallerstein, Koniec świata jaki znamy, Scholar, Warszawa 2004, pp. 173-179.

4 The secularization and religious pluralism, among others in: J. Beckford, Teoria spoleczna a religia, NOMOS, Kraków 2006.

5 See: F. A. Yates, Giordano Bruno and the Hermetic Tradition, Routledge, London 2001. 
dogma of the Trinity (Docetism), ${ }^{6}$ but his postulates to sciences have a broader scope. According to him physics was a science that dealt with the objective reality, therefore, it had a different character than mathematics (dealing with constructs of the human mind), it also was of a different nature than metaphysics. G. Bruno argued for methodological diversity in the analysis of reality and against the omnipotence of theology and its claim to control philosophy. G. Bruno is an example of emancipation of philosophy in terms of knowledge sources. ${ }^{7}$ With the same trend we will deal during the attempt to reject philosophy in the $18^{\text {th }}$ century. This time, the discourse on the authority of sources of knowledge was simplified to the problem of testing methods.

\section{EMANCIPATION OF SCIENTIFIC DISCIPLINES}

First, theology was supplanted by philosophy, and later the place of philosophy was occupied by science. The key issue was what determines the legitimacy of philosophical reasoning. Researchers treated philosophers in the same way as philosophers treated theologians before. Researchers referred to the argument of empiricism of research and hypothesis verification procedures. According to them the subject of research was to be the truth and not the good. In fact, in this sense, we can talk about the fetishisation of research methods. What is scientific and reflects the truths was to be decided by a proper research process, namely properly applied research methods. I. Wallerstein draws attention to the problem of determining the adequacy and characteristics of research methods in science, namely, who is to decide on the standards of proper application of the methods, and who will control the inspectors of the appropriateness of the methods. ${ }^{8}$ This problem resembles the main motive of Minority Report by P. K. Dick, which refers among others to the possibility of mistakes and manipulation of judges - seers adjudicating on the case before the offender commits the offense. ${ }^{9}$ What is then the extent to which we can be sure of the decisions given by the authorities and are there any control mechanisms on the guards?

In the $19^{\text {th }}$ century sciences which in short can be called the humanities (e.g. philosophy) could not cope with the direction set by the Newtonian - Cartesian science. Humanities could not challenge the competence of science to explain the physical world, and because of that they went more into a defensive position, determining the man as

${ }^{6}$ See: Ch. S. Clifton, Encyklopedia herezji i heretyków, Athens, Poznań 1996, pp. 66-67.

7 Not to share the fate of G. Bruno their scientific ideas had to hide to a bigger or smaller extent, for example Copernicus, Galileo, and I. Newton. For instance, 16 years after the death of G. Bruno, in the face of accusations of the Inquisition, Galileo denied the assumptions of the heliocentric concept. His views, Galileo dared to publish at the times of the papacy of his friend Urban VIII, but here he overestimated their friendship. Published in 1632 Dialogue Concerning the Two World System, which significantly supported the Copernican system, became the basis for the re-indictment of Galileo by the Inquisition. Brought to Rome, humbled himself before the Inquisition and filled the judgment of the Holy Office. Galileo spent the rest of his life in seclusion and under strict control. See: B. Russell, Religia i nauka, AND KIP, Warszawa 2006, pp. 23-30.

8 I. Wallerstein, Koniec świata jaki znamy, op. cit., pp. 242-245.

9 P. K. Dick, Minority Report, Golancz, London 2002. 
the subject of study, above all the spirituality and morality of the man. On the other hand, there were other fields added to social studies, such as economics, sociology and political science. According to I. Wallerstein, these fields usurped the methods and the splendour of science; what is more, they began to aspire to be nomothetic sciences. This nomothetic trio - as it was described by I. Wallerstein - with idiographic history, put themselves higher than philosophy and humanities. It should be added that natural sciences were similarly aloof, but, in relation to social sciences. ${ }^{10}$

Researchers to maintain their legitimacy and prestige could relate to social consequences of knowledge production, for example to technological improvements. This was a sufficient basis to make the actual separation of sciences from philosophy. The researchers were of the opinion that the only acceptable methods are empirical studies with verifiable hypotheses. Only with their help one could discover the so called universal truth. The reliance of humanism on virtues, the good and beauty in the pursuit of knowledge was totally unacceptable to scientists. This resulted among others from the fact that, according to them, science was to be axiologically neutral, and yet the values cannot be described as true or false. ${ }^{11}$

With time, the discourse between sciences exacerbated; the battle was fought not only for methodological and epistemological primacy, but also for prestige and dominance in social sphere. Authorities increasingly valued more scientists than humanists. Effective and impressive technology was more important than the discussion of values, that means, of greater importance was the possibility of technological superiority in armed conflicts than a reflection on the soul. As it was mentioned above, the humanities, not being able to compete on this level, retreated to the study of the good and beauty. The epistemological - methodological division, which took place, also had an impact on the institutional division of research and educational institutions. The institutionalisation of two scientific cultures and disciplines was taking place. This resulted in the current specialised colleges, departments, degrees and academic titles, scientific journals, etc. The divisions were even more detailed, for example specific disciplines were institutionalised by subtracting respective departments. ${ }^{12}$

Social Science, quickly were between two abrasive methodological legacies, that means natural sciences and humanities. This resulted in the division of social sciences in the respect of applied epistemology. Researchers followed two epistemological directions, namely idiographic and nomothetic. ${ }^{13}$ In the first case, social scientists

10 I. Wallerstein, Koniec świata jaki znamy, op. cit., pp. 246-248.

11 I. Wallerstein, Europejski uniwersalizm. Retoryka władzy, Scholar, Warszawa 2007, pp. 76-77.

12 Ibidem, pp. 77-79.

13 I. Wallerstein is against the fragmentation of social sciences to nomothetic and idiographic sciences, disciplines which are based on theories and based on the description. W. L. Goldfrank cites the influence of one of the promoters of I. Wallerstein, namely C. W. Mills, who spoke negatively about the great abstract theory and empiricism. C. W. Mills in his book The Sociological Imagination actually devoted two chapters to issues of great theoretical and abstract empiricism. In the first case he refers to the social system of T. Parsons, where he criticises the universal of the social order, accuses T. Parsons of trivialising crucial empirical problems, and suggests that the problems and solutions are only a very theoretical. The main problems of maintaining the social structure as a whole, C. W. Mills simplifies to different ways of integration. In great theories the monolithic concept do not survive the clashes with social diversity (this refers to historical, social, and cultural context). C. W. Mills opts for 
emphasised the exceptional nature of social phenomena, while the representatives of the second current stressed the comparability of human processes with the material ones. According to I. Wallerstein, two streams of research had an impact on social sciences, namely the research on complexity and culture. Studies on complexity decide on the complexity of a social systems, while the research on culture emphasises the social context and lack of homogeneity of social reality. According to I. Wallerstein, these two directions are to set trends in social sciences. Moreover, we are dealing with sociologisation of knowledge. ${ }^{14}$

In the very social sciences there is a discourse concerning the perspectives of the analysis of social reality. I. Wallerstein mentioned here three main antinomies: micro - macro, globality - locality, structure - activity. In the first case the problem depends on the preferences of the researcher, whereas in the two other cases the approach depends on emotional factors. ${ }^{15}$ The problem in social sciences is the fact of adoption of these perspectives as the sole and legitimate type of research. Recognition of only one point of view in the social reality analysis hinders the discourse on social sciences.

In the case of theory of international relations, we are dealing with the path which has already been cleared by the sociological, or political science theoretical thought. With regard to "theory of international relations", the issue that it is based on global approaches and macro perspectives. The scale and perspective from which the problem is presented in political sciences lead to a situation where huge deduction "edifices" are constructed, which in addition to their size, syntactic tricks and fetishisation of notions do not offer any possibility of fulfilling the criterion of scientific progress. ${ }^{16}$ While

the presence of orders of different types (i.e., different foundations of the order), he writes that: "there is no 'grand theory', there is no universal model that would allow to understand the unity of the social structure, there is no single answer to the constant discussion on the old question of social order taken überhaupt [ed. at all]". T. Parsons' assumptions about the harmony of order and not having to explain the mechanisms of interaction do not provide an explanation to the conflict, social changes and history. C. W. Mills writes that: "the cause of the birth of the great theory is the pre-selected level of thought, so general, that the practicing it people are not logically able to reach the level of observation. As great theorists, they never leave a high level of generalisations to problems in their historical and structural context". In the second case, C. W. Mills criticises the nature of work and assumptions of abstract empiricists. He refers to the technologisation of quantitative and qualitative research of society. Public opinion research went from the domain of reflects of humanists to the natural sciences. On the other hand, research conducted by the representatives of this empiricism "depend on accumulation of detail but without paying necessary attention to the form - in fact, the only form that appears often comes from the typesetters and bookbinders. Details, no matter how numerous, do not convince us of anything to which it is worth to be convinced". C. W. Mills stresses the link between the method and style of action with the government or simply the administrative apparatus. At this point, it shows a convergence of views on I. Wallerstein transformations applied sciences and using them by the government. The object of study of the abstract empiricists is determined by limitations of the scientific method (which is a reflection of science). C. W. Mills writes about the transition from social philosophy to empirical sociology; quoted in: C. W. Mills, Wyobraźnia socjologiczna, PWN, Warszawa 2008, pp. 78-144. See also: W. L. Goldfrank, Paradigm Regained? The Rules of Wallersiein's World - The Method, "Journal of World - Systems. Research" 2000, Vol. XI, No. 2, pp. 150-195.

14 I. Wallerstein, Koniec świata jaki znamy, op. cit., pp. 223-230.

15 Ibidem, p. 242.

16 For example, a national criterion of progress in the pursuit of truth proposed by K. R. Popper; see: K. R. Popper, W poszukiwaniu lepszego świata, KiW, Warszawa 1997, p. 57. 
structuring the reality of the international relations by its idealisation, researchers and theoreticians often transgress borders to enter the grounds of unrealised deformation, transcendentalisation and fictionalisation. ${ }^{17}$ The so obtained picture becomes merely an extended structural metaphor which is dangerous inasmuch as it is used to provide ideological justification of activities carried out within the framework of the international relations science.

The problem which appears to be of relevance on theoretical grounds is a situation where metaphorical efforts become the essence of scientific narrative. Issues arise where the efficiency of the scientific process is replaced with the efficiency of narrative stylistics, or vividness of metaphor. Under no circumstances can this statement be regarded as a critical voice against metaphors as they are immanent elements of the language structure. This statement assumes, however, that it will not be possible to construct longer statements or narratives without a metaphor. However, a situation where in the scientific process, the scientist focuses solely on constructing a set of metaphors whose sole purpose is "rewriting" of knowledge or issues generally acknowledge or explored so that they become "refreshed" or even controversial certainly is a problem. A good example of it may be an allusion to the achievements in the field of physics or biology through the use of metaphors.

\section{DYNAMICS OF CHANGES IN SOCIAL SCIENCES}

I. Wallerstein puts forward the postulate of rational restructuring of sciences of social reality and reintegration of knowledge of what is real and what is good. In the first case, it is important to assume that the patterns of human behaviour are the appropriate subject of study and the assumption of universality should be rejected. In the case of reintegration of knowledge I. Wallerstein equates the good and truth with material rationality. This stems from the fact that, in the long term, the good and truth can also be equal. The truth is nothing else but the best choice for specific opportunities. The consequence of these considerations is the rejection of the assumption of conflict between two cultures, that is two approaches. Therefore I. Wallerstein supports the need to build institutions which would increase the collective knowledge. The difficulty in building a new structure of knowledge can result from posing a threat to subjects deriving the greatest benefits from the unequal distribution of power and resources in the world. ${ }^{18}$

The modern world is characterised by a wide range of variation. Diversity discourses and objectives affect among others the division of labour. This division in the capitalist system is assessed as very positive, as it increases productivity. In addition, it leads to specialisation in different areas of social life, which increases the space for particular types of behaviour of individuals. We are dealing with increased heterogeneity of society. ${ }^{19}$ The description of global processes follows two directions - polarisation

17 Cf. L. Nowak, On the Concealed Unity of Social and Natural Sciences, http://strebski.dyktatura.info/wp-content/texts/philosophy/Nowak02.pdf (6.11.2012).

18 I. Wallerstein, Koniec świata jaki znamy, op. cit., pp. 229-230.

19 Ibidem, pp. 192-203. 
and conventionalisation. On one hand we are dealing with increased heterogeneity of the world, on the other hand, we can observe an increase of homogeneity. A consequence of these approaches is a presentation of processes through the prism of combativeness or harmonisation. I. Wallerstein points out that a similar situation is in the case of knowledge. Knowledge structures are also subject to appropriation as a result of dominance of particular opinions. Moreover, today's knowledge structures show their strength through a claim to universal validity, that means the claim to universal knowledge.

In addition, I. Wallerstein draws attention to other processes which take place in social sciences, including the increase in the number of scientists and the still present paradigm of originality in research. This has consequences for social sciences - heterogeneous and homogeneous. The originality requirement forces the search for research niches, and the consequence of this is the necessity of establishing individual research as something extraordinary and different from the research of other scientists. Its consequence is also an increasing number of researchers, which, on one hand, enforces more frequent contacts, on the other hand, results in the need of specialisation and fragmentation of knowledge. The threat which may arise from this is the way of shaping the scientific contacts, and therefore, the way of creating the structure of knowledge. Selection may be based on more democratic processes (formation of new subdisciplines) or less democratic ones (formation of a scientific elite). A key issue is what determines the emergence of a specialisation in specific disciplines. In fact, according to I. Wallerstein, the practice is that people themselves make the division and fragmentation of knowledge, and only later they seek justification for their individualism and argue for their demarcation, due to the increase of knowledge. Another practice is to enter into large-scale issues; therefore, in its consequences it will be a practice homogenising science. For example, the conflicting current of the description of social relations will necessitate to refer to various disciplines and subdisciplines. A consequence of such practices will be a synthetic presentation of knowledge, that means, ascribing universality to knowledge. The question is whether a considerable accumulation of knowledge in one current and a major synthesis of its achievements would not lead to the emergence of a new specialisation. ${ }^{20}$

The rivalry between the idiographic and nomothetic factions for the level of objectivity influenced the development of two opposite analytical approaches - micro and macro scales. In the beginning the macro scale was the dominant perspective, but as a result of progressive specialisation the micro perspective began to be strengthened. This is the natural direction of development of social sciences and the research community. The requirement of originality and objectivity could best be achieved by reducing the subject of research. On one hand it gave the opportunity to focus on new areas of research, which had not been previously discussed, on the other hand it allowed the use of more precise research instruments. I. Wallerstein describes this phenomenon as "mentality of microscope" - that is, fragmentarisation, reduction and specialisation. This

20 Ibidem, p. 196. 
microscopisation of science is one of the factors which influences the increase of differentiation between idiographic and nomothetic sciences. ${ }^{21}$

In principle, researchers belonging to the dominant paradigm of interpretation would ignore the importance of other currents, and other representatives will stress their undeserved marginalisation and relativity of paradigms at all. In this context, we will deal with different visions of science: democratic (deliberative) and omnipotent (non-discursive). I. Wallerstein himself is in favour of existence of many possible paradigms; however, such a position would assume that not all paradigms are useful to the same extent. ${ }^{22}$

An important scientific problem is the originality of research, and this enforces competition between scientists. Superiority of one paradigm over another can only result from a strong institutional position, that means, the strength of a particular current will be determined by how deeply it is ingrained in science, understood as the structure of research institutions, universities, etc. This institutional legitimacy can replace a real discourse in science, since it prevents a reliable exchange of knowledge. In general, the public aspect of knowledge should be based on what R. K. Merton called disinterestedness, that is one of the pillars of the ethos of science. ${ }^{23}$ However, the transparency of science by the verifiability does not answer to the problem of competition not only in research but also in the sphere of competing ambitions and rivalry for influence in institutional science. The sphere of science is not really different from politics or other spheres of social life. "In the world of science there is, of course, competition, reinforced by an emphasis on priority as a criterion of performance; in competition there can easily occur a temptation to eclipse rivals by illicit means. In scientific research the feasibility of such impulses is small. Favouritism, clique, numerous though trivial publications - these and other methods are often used to raise self-esteem", ${ }^{24}$ writes R. K. Merton. In addition, actual discourse in science can be suppressed by the so-called scientific authorities, which by their symbolic capital and esteem influence the persistence of certain perspective of research. It may be manifested as a lack of opportunities to present new ideas or approaches only due to the domination of a certain scientific authority.

In a broader context of the discussion on the development of science T. S. Kuhn wrote about the so-called normal science, which was closely related to paradigms. The paradigm of science is nothing else but accepted patterns of scientific practice, which means dominant sets of ideas. A specific set of ideas, represented among others by flagship scientific works, determines the significance of problems and the need for specific research methods. What should be characteristic for this set? According to T. S. Kuhn, its main features are originality and attractiveness, and their uniqueness should be so strong that it could focus the attention of many scientists in such a way that they would not undertake research on competing ideas. Dominant sets of ideas, theories, etc., form

${ }^{21}$ I. Wallerstein, Koniec świata jaki znamy, op. cit., pp. 249-250; I. Wallerstein, Europejski uniwersalizm. Retoryka władzy, op. cit., p. 25.

22 I. Wallerstein, Koniec świata jaki znamy, op. cit., p. 198.

23 R. K. Merton, Teoria socjologiczna i struktura społeczna, PWN, Warszawa 2002, pp. 589-590.

24 Ibidem, p. 589. 
something which can be called a tradition of scientific research. ${ }^{25}$ In this context, the theories of I. Wallerstein on the form of social sciences and the methods used to analyse social reality are merely claims of priority. This claim relates to the legitimacy of its specific analysis of world-systems as the primary. Moreover, this claim concerns the vision of social reality and the directions of its changes, which in itself - writing ironically - from the perspective of the development of science and historical system is not unusual and unique.

I. Wallerstein, with the analysis of specialisation and methods in science, draws attention to a different status of anthropologists and orientalists. This difference is presented in comparison with idiographic and nomothetic sciences, which, together with their development, sought to improve the status of their methodology. The specificity of the subject of research of anthropologists and orientalists became a justification for lower requirements of objectivity; therefore, to avoid allegations of negligible scientific character, representatives of these sciences limited the subject matter of their research. ${ }^{26}$ At the beginning this was due to the domination of the Western world researchers, who developed these sciences. In fact, they were strangers who showed up in a world of a different culture, religion or language. This strangeness affected the manner of their research and often made it difficult to understand the broad context of other cultures. A major problem was the issue of active participation in the research of different cultures, that is the issue of commitment. ${ }^{27}$ A different point of view shared the nomothetic trio that rejected the distance and postulated the proximity. In the case of nomothetic sciences the proximity was to facilitate collecting the research materials. ${ }^{28}$ Study on a foreign culture was connected with the unavailability of a lot of data, which had to influence the results of conducted surveys. It seems obvious that the researchers, not being able to use data similar to that available in their own countries, had to eliminate the variables, which was not without an effect on the calculated indices. ${ }^{29} \mathrm{~A}$ similar problem had the nomothetic trio who had problems with completing the data from the

25 T. S. Kuhn, Struktura rewolucji naukowych, Aletheia, Warszawa 2009, pp. 31-98; Z. Hajduk, Metodologia nauki, Katolicki Uniwersytet Lubelski, Lublin 2002, pp. 99-104.

26 I. Wallerstein, Koniec świata jaki znamy, op. cit., pp. 250-251.

27 M. C. Nussbaum points to the problem of research of different cultures or ethnic groups because of the prospect of identity. Research analysis due to cultural or racial prospects encounters the problem of identity of researchers. Should the approach of researchers have either an inclusive or exclusive character? Does the mere fact of our origin (e.g. different skin colour) should lead to a closed identity politics of the object of study or not? This is a problem that did not concern I. Wallerstein, because his perspective was based on the denial of the universalist approach of the western world to strangers, which led to the imposition of a particular interpretation of foreign cultures. M. C. Nussbaum points to the problem connected with the ability to create closed identity applying to both researchers and the test subject of research. One example is African-American studies, in which they are familiar with the views in favour of non-African Americans researchers exclusion. There can be found some positions, which de facto deny the legitimacy of research because of the lack of something, which might be called a lack of authenticity, the consequence may be afrocentrism. More in: M. C. Nussbaum, $W$ trosce o czlowieczeństwo: klasyczna obrona reformy kształcenia ogólnego, NDSzW, Wrocław 2008, pp. 161-201.

28 I. Wallerstein, Koniec świata jaki znamy, op. cit., p. 250.

29 Ibidem, p. 252. 
past. The result of this was the focus of nomothetic sciences on the present and historical science on the past.

Undeniably, various approaches can be identified within the scope of pursuit of a theoretical justification of the grounds of international relations science, e.g. different incarnations of realism, liberalism, institutionalism, or Marxism. It has to be noted at the same time that these theoretical positions are close to paradigms, concepts, notional and interpretational schemes and often enough to the blown metaphorical narratives rather that what can justifiably referred to as the "theory". This variety will tend to grow in connection with that I. Wallerstein referred to as the originality requirement.

To describe the phenomenon of pursuit of "novelty", S. Kozyr-Kowalski used the notion of "cainotism" [Pol. kainotyzm]. This phenomenon lead to departure from reliable thinking in science and spoiling it. The pursuit of novelty results in a situation where the representatives of social sciences lose their rooting in the sources and classics, which only favours discrimination of specific research methods (e.g. historical and comparative methods) and even the overall output of their own discipline. ${ }^{30}$ Its consequence is a methodological anarchy and messing up of science with temporary "models". Leaving aside the considerations of S. Kozyr-Kowalski, another process can be identified which uses the fashion for any type of "anarchy" to justify lack of the actual research process in individual disciplines of social sciences. This "forgery" may be effective, yet has nothing to do with the efficiency in identifying the subject matter of the research and development of theoretical and methodological base. ${ }^{31}$

Furthermore, it has to be emphasised that in the case of construction of "comprehensive theoretical edifices" in the theory of international relations, there may occur strong reductive efforts deriving from lack of resolution of basic ontological and epistemological problems. A good example of it will be lack of possibilities of defining the factors which are important in the process of building of an international society, as well as unique identification what the causative and constituent elements of this society are. A consequence of failure to resolve the basic ontological and epistemological issues will be the lack of possibilities of effective determination of the specific nature of dissimilarity of factors and subjects and their importance in the mutual relations.

\section{THE CONSEQUENCES OF THE DEVELOPMENT OF SOCIAL SCIENCES}

A consequence of the methodological development of social sciences was the divorce with philosophy, which resulted in the abandonment of research on the good in the area of knowledge. On the other hand, studies on the truth were reduced to microscopic positivism. ${ }^{32}$ According to I. Wallerstein, objectification of social sciences led to "subservience" to the reformism of the government, and the very social sciences often begun to call themselves applied social sciences. Of course, one should pay attention to

${ }^{30}$ Cf. S. Kozyr-Kowalski, Uniwersytet a rynek, UAM, Poznań 2005 (Chapter I).

31 Cf. A. Sokal, J. Bricmont, Modne bzdury. O nadużywaniu pojęć z zakresu nauk ścistych przez postmodernistycznych intelektualistów, Prószyński i S-ka, Warszawa 2004.

32 I. Wallerstein, Koniec świata jaki znamy, op. cit., p. 252. 
the relevance of his reflection on the objectification of social sciences with the development of capitalism; however, one should not be deluded that science began to be "subservient" only due to the influence of the capitalist economy. Science, like other forms of human activity, does not develop in a social vacuum, and it has always been used in connection with legitimacy of authority (state, economic one, etc.). According to I. Wallerstein, close involvement of social sciences led to the break with neutrality research. $^{33}$

One can reflect on the importance of good for I. Wallerstein, referring to the platonic triad of good - beautiful - truth. Evaluation of human activities shifted from the area of aesthetics to ethics, and what the man creates should be both useful and true. I. Wallerstein opts for a comprehensive analysis of natural and social reality. ${ }^{34} \mathrm{Knowl}-$ edge cannot be segmented, since its contents are the components of the universe. The products of the man cannot be autonomous in relation to morality and the laws of nature, that means, beyond good and evil. Knowledge should be used to improve the man and to create a good society. I. Wallerstein calls for a dynamic conception of knowledge, which itself is not a final destination only a desire to reach the target. ${ }^{35}$

I. Wallerstein drew attention to legitimising the division into two cultures and the destabilisation of this division in the late twentieth century, which should be attributed to structural changes in the scientific community. At the end of the twentieth century, two principal trends in science crystallised, namely the study of complexity in natural science and cultural studies in humanities. The trend in research on complexity denied the Newtonian linear determinism and the associated assumption of time reversibility. These assumptions contributed to the analysis of not only natural systems and not only on the macro level. However, in the case of cultural studies we deal with "relativism", because these studies disputed the universal concepts of beauty and the good. Certainly, humanities refer to being different in different cultural studies, although the approach had to be biased and represent the point of view, which in short can be called Europocentric (or generally associated with the Western culture). Important in these studies became the social context and the appreciation of the role of societies and cultures previously marginalised. This applies to different points of view, perception or interpretation represented by individuals, groups, societies, nations, countries, etc. ${ }^{36}$

What connects these trends? I. Wallerstein says that it is a negation of division into two cultures, which has become inefficient and unrealistic to maintain in research. In

33 I. Wallerstein points out that interest in social sciences of the governing authorities resulted from dynamic socio-political changes (e.g., revolution). Social and political effects of these processes are reflected in the desire to know their character. Learning can contribute to better control over them, and thus secure the position of the government. Therefore, general issues related to social science refering to epistemological - methodological identity were connected with a shift towards applied social science. The asecurative nature of the applied social sciences to the prevailing influence on their perception - in this case for I. Wallerstein was negative due to the tertiary nature of social sciences to the government. See also in: I. Wallerstein, Europejski uniwersalizm. Retoryka władzy, op. cit., pp. $65-86$.

\footnotetext{
34 I. Wallerstein, Koniec świata jaki znamy, op. cit., p. 253.

35 Ibidem, p. 253.

${ }^{36}$ I. Wallerstein, Europejski uniwersalizm. Retoryka władzy, op. cit., pp. 82-83.
} 
addition, the social sciences to a different extent and degree adopted the idea of complexity. This led to different assumptions:

- social system is the most complex system,

- science is a component of culture,

- cultural production is a part of the authority/power structure. ${ }^{37}$

Drawing from many disciplines and subdisciplines by social sciences led to blurring their identities, because a lot of sciences began to use diverse methodologies. In addition, there has been and sill is occurring further microscopisation of the subject of research - the emergence of other disciplines, for example gender studies, queer, etc. With the emergence of new disciplines comes their institutionalisation at universities or other research-teaching institutions. Popularisation of science intensified the rivalry between research institutions, and the rivalry concerns both financial resources and the souls. According to I. Wallerstein, this methodological - epistemological blur is also relevant to the current the world - system, because it strains one of the strongest European universalisms, namely scientific universalism. One may wonder if this will lead to the anarchy of the world-system, as the American sociologist writes. Or is it rather an expression of flexibility of the capitalist world-economy? One may perversely assume that the habitual universality (European) no longer has any relevance to the capitalist economy, because the spatial extent of the capitalist world - economy embraced the whole globe, and thus the power of the authority of European universalism does not matter. What matters is the effective functioning of capitalism and it rather needs the spread of scientific knowledge at least for two reasons: (1) because of what L. Althusser called reproduction of labour power, ${ }^{38}(2)$ externalisation of costs of research and scientific activities, where capitalism derives from. Of course we can introduce some other reasons, but all this will not stick to the convention core versus peripheral areas.

A question which can be asked is as follows: What are the consequences of international relations theory for the development of social sciences? Has the "theory of international relations" not become doubly ideological? On one hand, it is a great "realm of notions", which is to legitimise the "scientific nature" of the international relations science, on other it is a knowledge justifying actions of governments (states, societies, etc.) within the international society. At this point, the process of instrumentalisation of the "theory of international relations" on various dimensions calls for an in-depth exploration.

Attention should be also drawn to the microscopisation effect as a trend in dividing the subject of research in science in general - it is a break in the exploration of the international society which manifests in the theoretical development of research and integration, globalisation, security, etc. A consequence of aspiration for theoretical taking effect of the individual subdisciplines will be a reckless expansion of "great theoretical notional edifices", which although built with enthusiasm will not match the great "zoning plans" in the international society research. The "new edifices" will probably be visually effective, however not functional, and may not correspond to each other. Some of

37 Ibidem, pp. 83-84.

38 L. Althusser, Ideologie i aparaty ideologiczne państwa, http://www.filozofia.uw.edu.pl/skfm/ publikacje/althusser05.pdf (30.11.2011). 
them will be but modest shelters clad in beautiful metaphors which will be the consequence of lack of real research process but also of sloppiness and/or ignorance.

$* * *$

The article contains an analysis of the concept of I. Wallerstein on the emancipation of individual sciences with a particular emphasis on social sciences. The text addresses the following issues: (1) the directions of emancipation, (2) the processes of emancipation, (3) the dynamics of changes in the social sciences, and (4) the effects of the change. In addition to the main theses of I. Wallerstein, the text also refers to the achievements of T. S. Kuhn, R. K. Merton and C. W. Mills, which allowed for a consideration of the problem in a broader context.

Identification of implications for the development of the "theory of international relations" was of considerable importance, especially in connection with the general social science development trends pointed out by I. Wallerstein. The paper discusses only selected issues related to microscopisation, idealisation, use of metaphor, deformation, transcendentalisation, fictionalisation and fetishisation of notions in the "theory of international relations". The scientific works of L. Nowak and S. Kozyr-Kowalski contributed made a considerable contribution to the analysis in this respect.

A major problem of the development of sciences (including social sciences) was the fact of accepting the Newtonian - Cartesian scheme of research, which significantly coincided with the logic of the capitalist economy. The capitalist world-economy to grow, that means to develop the added value, had to rely on the efficiency and rationalisation of operations. Rationalisation and efficiency was ensured by the sciences based on the empirical methodology of nomothetic sciences. Social sciences, so as not to be marginalised, had to largely become flexible to authority, that was the only way they could prove their practicality and usefulness. Objectification of social sciences made it difficult to reflect on the study of social reality; in principle, the reflection was reduced to the logic of activities of the capitalist world-economy. I. Wallerstein's demands for changes in these trends included: (1) "utopistics" or the idea of searching for the rationality of material and what goes with other potential solutions in the shaping of social reality, (2) attempt to bridge the gap between two cultures in science.

At this point, the issue related to the double idelogisation of the theory of international relations should be considered on a more detailed level and continued - (1) with respect to the "notion of kingdom" and "aesthetic use of metaphor", (2) with respect to the instrumental tool legitimising the activities of various entities within the scope of international society.

\section{ABSTRACT}

This paper presents an analysis of the social science development concept of Immanuel Wallerstein. In general terms we can say that the development of social sciences was based on a process of emancipation of individual subjects of research and validation of research methods. I. Wallerstein drew attention to the process of emancipation of individual disciplines, therefore we can talk about the separation of philosophy, followed by social sciences and, negatively eval- 
uated by I. Wallerstein, applied social sciences. With the constitution of individual disciplines we dealt with the process of polarising methodological positions, which can be roughly described as the concept of two cultures. The text describes the following issues: (1) the directions of emancipation of scientific disciplines, (2) the processes of emancipation of scientific disciplines, (3) the dynamics of changes in social sciences, (4) the effects of changes occurring in sciences. In addition to the main assumptions of I. Wallerstein on science, the text attempts to confront these assumptions with the achievements of T. S. Kuhn, R. K. Merton and C. W. Mills. The aim of the article is to point out the implications for the "theory of international relations" deriving from the general trends in the development of social sciences. This issue has come down to only selected issues of: microscopisation, idealisation, metaphorical use, deformation, transcendentalisation, fictionalisation and fetishisation of notions in the "theory of international relations".

\section{ROZWÓJ NAUK SPOLECZNYCH W ROZWAŻANIACH IMMANUELA WALLERSTEINA - IMPLIKACJE DLA TEORII STOSUNKÓW MIĘDZYNARODOWYCH}

\section{STRESZCZENIE}

Artykuł przedstawia analizę koncepcji rozwoju nauk społecznych Immanuela Wallersteina. W ogólnym zarysie można powiedzieć, że rozwój nauk społecznych opierał się na procesie emancypacji poszczególnych przedmiotów badań i uprawomocnienia się metod badawczych. I. Wallerstein zwracał uwagę na proces emancypacyjny poszczególnych dyscyplin, dlatego też możemy mówić o wyodrębnieniu się filozofii, w dalszej kolejności nauk społecznych oraz negatywnie ocenianych przez I. Wallersteina nauk społecznych stosowanych. Wraz z konstytuowaniem się poszczególnych dyscyplin naukowych mieliśmy do czynienia z polaryzacją stanowisk metodologicznych, które to w skrócie można określić pojęciem $d$ wóch kultur. W tekście podjęto następująca problematykę: 1) kierunki emancypacji dyscyplin naukowych, 2) procesy emancypacyjne dyscyplin naukowych, 3) dynamikę zmian w naukach społecznych, 4) skutki zmian występujących w naukach. Oprócz głównych założeń myśli I. Wallersteina na temat nauki w tekście podjęto próbę konfrontacji tych założeń z dorobkiem T. S. Kuhna, R. K. Mertona i C. W. Millsa. W artykule wskazano implikacje dla "teorii stosunków międzynarodowych" w związku z ogólnymi procesami rozwoju nauk społecznych. Problematyka ta została sprowadzona jedynie do wybranych kwestii: mikroskopizacji, idealizacji, metaforyki, deformacji, transcendentalizacji, fikcjonalizacji i fetyszyzacji pojęć w "teorii stosunków międzynarodowych". 